\title{
Sustainable development from an evolutionary perspective
}

\section{Bastiaan (Bas) SCHRAUWEN \\ Independent scholar, Germany}

\section{Abstract:}

Aim: awareness of the inherent unsustainability of past economic development, the magnitude and multidimensionality of the resulting environmental problems and the urgency of a paradigm shift in politics and economics.

Design / Research methods: reflection on Matthias Glaubrecht's book "Das Ende der Evolution" (The End of Evolution). Additionally Yuval Harari's book "Sapiens" and some online sources were used.

Conclusions / findings: An evolutionary developed cognitive superiority has made Homo sapiens not only to the most successful but also the most destructive species ever, which makes a drastic shift towards sustainable development is overdue in the 21 st century.

Originality / value of the article: highlighting the slow and merciless mechanisms of evolution and its big cycles, raising more awareness of the vulnerability of mankind and the necessity for a paradigm shift.

Implications of the research (if applicable): urgency of sustainable development in politics, economics and research.

Keywords: sustainable development, evolution, environmental economics, politics

JEL: B52, Q01, Q59

Correspondence address: Bastiaan (Bas) Schrauwen, independent scholar, Carlstrasse 13, 17235 Neustrelitz, Germany E-mail: bastiaan.schrauwen@gmail.com Received: 26.07.2020, Revised: 07.09.2020, Accepted: 20.09.2020

doi: http://dx.doi.org/10.29015/cerem.883 


\section{Introduction}

Sustainable development and evolution are two things that at first glance do not seem to have much in common. Evolution is the basic theory of biology; sustainable development is a concept that should reconcile protection of the environment and economic development. The concept of sustainable development was coined by a UN Commission on environment and development. This so-called Brundtland report defined sustainable development as "the development that meets the needs of the present without compromising the ability of future generations to meet their own needs" (WCED 1987: 16).

In this Brundtland report sustainable development was meant as sustainable human development. However, it is possible to see sustainable development in nature as well: Sustainable development of plants and animals and whole ecosystems, over millions of years, in the course of evolution. It is a development that leads to more abundance of life and more resilience of ecosystems.

I will discuss these tenacious and diversifying aspects of sustainable development in natural evolution first. Then I will highlight the unsustainable development in human evolution so far, and I will conclude with the thesis that our evolutionary developed ability to think rationally still may enable us humans to restore damage done to the ecosystems of the earth, just like it enabled us to inflict this damage in the first place.

\section{Sustainable and unsustainable development in human evolution}

In 1859 Charles Darwin published his world-changing book „On the Origin of Species By Means of Natural Selection or the Preservation of Favoured Races in the Struggle for Life" (Darwin 1859), postulating that evolution, and not divine creation, is the origin of life. We now know that a set of DNA molecules, identical in every cell of a specific organism, is a blueprint of the organism as a whole. In these molecules random mutations may occur, resulting in slightly different characteristics of the organism. Mostly these changes are not profitable at all and the slightly different organism will not survive in the struggle for life. However, sometimes 
these changes are profitable and the slightly different organism will win in the struggle for life and its DNA will be passed on to the next generations. A small step of evolution, which eventually may lead to a new species. But it will take a long time, a really long time: millions of years. Extinction of species is a normal process as well For that reason it takes a very long time until a new species really appears. And a long time, again, really means a long time: millions of years. From time to time some species disappear from the scene and go extinct as well, because of changes in microclimate, natural disasters and competition with new species. This appearance and disappearance of species is part of the normal process of evolution but in the last two hundred years, at an accelerating rate, we humans cause millions of species to disappear and go extinct (Glaubrecht 2019 - 417) and we cannot expect nature to repair the damage sometime soon. Of course nature will repair the damage, but it will do so in its own pace. It may take ten million years for natural evolution to develop a world as abundant as our grandparents used to know it. However, it would be a different world with different plants and animals and most probably without us.

Last time, after the dinosaur extinction, it took about ten million years before nature regained its previous abundance, its previous biodiversity. Sixty five million years ago a big meteorite crashed into the Gulf of Mexico, causing a layer of dust darkening the sky worldwide for a long time. Temperatures suddenly fell, plants died without light, animals died for cold and lack of food: $70 \%$ of all species disappeared. The world of the dinosaurs was lost and about ten million years later a new world of mammals, birds and other creatures, the world we are familiar with today, had appeared (Lowery, Fraass 2019). This aspect of evolution shows its large time scales but also its tenacity.

This is sustainability: nature's evolution never gives up. Massive climate changes caused mass extinctions at least five times in earth's history. But never all life disappeared, and always evolution accelerated after a mass extinction event because of the many free ecological niches and low pressure of competitors and enemies. Evolution of the surviving plants and animals was ten times faster after the extinction of the dinosaurs than before, a recent study showed. But still: ten million years to develop the previous diversity (Halliday 2016). This diversity is an 
enormous abundance of specialized species. Many different food relationships develop: "to eat and to be eaten" is a basic principle of life. But many forms of mutual dependency or mutual assistance, if you prefer, develop as well. Flying insects looking for nectar in flowers are essential for pollination of most plants; the underground mouldy network of mushrooms gets its energy-rich nutrition from trees and helps them to better absorb water and minerals; certain small fish clean the teeth of bigger fish and get nutrition in return. Diversity is essential for sustainability, because it guarantees every role in the ecosystem to be played. If an organism disappears from the system, for whatever reason, another one will take its place. And even more important: diversity makes a system resilient. An intact, diverse ecosystem, like a primeval forest, is much more resilient than a poor one, like a commercial monoculture forest. One species of beetle will not be a real threat to a primeval forest, like it is currently to our monoculture pine forests, because younger trees and other tree species would not be affected as severely. Rather the beetle would bring about the regeneration of many species and the rejuvenation of the forest. A study on the population dynamics of the bark beetle points out that "these outbreaks have strong negative consequences on ecosystem services like provisioning of clean water and timber, and the regulation of climate and carbon storage, but paradoxically facilitate local biodiversity" (Biedermann et al. 2019).

Man is part of nature as we know it, too. We are primates, animals adapted to life in the trees of tropical forests. We belong to a subgroup called the dry-nosed primates (Glaubrecht 2019: 75). The taxonomical group of the dry-nosed primates consists of two monkey families on both sides of the Atlantic Ocean, and the tailless family of the great apes. This is our taxonomical family, which we share with orangutans, gorillas and chimpanzees. For some reason, our ancestors one day decided or were forced to leave the trees of the tropical forests in central Africa and make a living on the savanna. They had learned to use sticks and stones as tools and weapons and were clever enough to make them sharper, and more effective. They evolved into a new evolutionary branch of species, humans, Homo in Latin, great apes adapted to life in an open landscape. About a dozen species of Homo developed in the course of the following millions of years (Glaubrecht 2019: 80): a diversity that optimized the chance for this new kind of apes to find its role in the 
new environment. Some went upright and lost most of their fur, which enabled them to run after prey animals and cool their bodies by sweating (Lieberman, Bramble 2007). About 1,900,000 years ago some of them left Africa. Bit by bit, in the course of many generations, they spread over the whole world. Their life still was sustainable, like that of the animals around them. They were hunter-gatherers. When hunting, they hunted like other hunting animals and usually caught young, weak and sick individuals that are easiest to get.

We are not one of these early species of man, though, we are Homo sapiens. Homo sapiens left Africa about 70.000 years ago, 1,780,000 years after earlier species of Homo (Glaubrecht 2019: 175, 190). We have been the only human species for a long time now, so apparently we killed the other ones anywhere we met them. Not only other human species but nature in general suffered massively wherever Homo sapiens entered the scene. Competing predators like wolves, bears and lions as well as big animals like elephants, mastodonts, rhinoceroses, aurochses and bison either were exterminated or decimated. It is nothing new, it was like that since the first Homo sapiens left Africa (Glaubrecht 2019: 194). We are the deadliest species that ever existed on earth; Tyrannosaurus Rex was a harmless creature compared to us.

What made us so much more dangerous than other species of man? It was an evolutionary change in the brain of early Homo sapiens (Glaubrecht 2019: 136)). It enabled him to think beyond the here and now, to think abstractly, to imagine nonexistent or not yet existing things and situations. This was a new layer of consciousness, so to say. It was this Cognitive Revolution, about 70,000 years ago, that made the difference (Harari 2014: 368). It allowed rational thinking and this led to an incredible acceleration of man's evolution. Not an evolution in the biological sense of the word, no mutational changes in the DNA, no changes in our physical constitution, but big changes in our abilities. We developed more sophisticated languages, which enabled us to communicate much better, which enabled us to cooperate much more effectively. We developed cultures and we developed agriculture. We achieved an Agricultural Revolution about 10,000 years ago and another one, the Industrial Revolution about 220 years ago. Both the Agricultural and the Industrial Revolution provided food and wealth for more people. The world 
population began to grow, fist slowly, but ever faster and faster. We were a relatively constant number of about 4 million people until about 4,000 BC. Then an exponential growth started: 190 million people at the beginning of the Christian era, 600 million in $1700,1.65$ billion in 1900, 3 billion in 1960, 7.6 billion now (Glaubrecht 2019: 243).

In modern times, with fire weapons, chain saws, agricultural machinery, artificial fertilisers and pesticides, man has become almighty on earth. If evolution is a contest, we won the cup. We are the crown of creation, the crown of evolution, we think. But we might as well be the stupidest creature in the world, digging its own grave. It wasn't until the 1970s that we started to become aware of the fact that we still are part of nature, depending on its ecosystems for our survival, and nevertheless on the very best way to destroy it all. It may not seem so relevant to us that there haven't been any aurochses, elephants, lions and wolves around in most of Europe for ages already, we survived very well without them. But we have not only been decimating big animals everywhere. Very many smaller animal species and plants have been undergoing the same fate, at a still accelerating rate. The destruction of their natural habitats to create more room for cattle and agricultural lands and more intensive fishery, too, have been the main reason for the loss of so many species of plants and animals. Of course, the need for us to do so is the relentless growth of the human world population. Can we secure food, fresh water and clean air for a world population of ten billion people by the end of the century, while fish disappear, soils degrade, glaciers melt and forests burn? It is a challenge, to say the least. Overpopulation, environmental pollution, mass extinction and climate change are four big scary monsters that are standing right in front of us. No wonder we are paralyzed when we look them in the face. They are mighty boomerangs that could make the human world population collapse. But as long as we still can feed most people, do not feel the consequences of mass extinction all too harsh yet, and climate change did not escalate right away, it is still easy to look the other way and to believe the monsters are not so big at all. The cognitive revolution, that inspired us 70.000 years ago to embark on a conquest of the world, has shown how fast our cognition, our rational understanding, can change who we are. We developed sophisticated languages, script, agriculture, towns, countries, multiple 
transport systems, companies, industry, science, medicine and information technology. What takes millions of years for natural evolution, takes a hundred years or less for us. Unfortunately, it brought us on the brink of extinction in this 21 st century. "Pride goes before destruction, and a haughty spirit before a fall", the biblical book of Proverbs reads (New International Version, Pr. 16.18).

\section{Concluding remarks}

Since the Cognitive Revolution Homo sapiens has been going through a kind of highspeed evolution, accelerating exponentially. We had one blind spot though, all the way from prehistoric times through the industrial era, but especially in these last two hundred years: we depend on intact ecosystems to stabilize the climate and secure food, clean water and clean air. If we do not want our cultures and our populations to collapse in the coming centuries, we need another leap of highspeed evolution right now.

In fact we did start this revolution in the second half of the 20th century already. An awareness of environmental problems came up in the 1970s, ever more scientific research on the topic deepened our understanding, green political parties appeared and protection of the environment became a general political point of interest. The United Nations organized summits, international declarations were drawn up and accepted; environmental laws were put in place. We are able to realize a sustainability revolution in fishery, agriculture and forestry, and manage a zero carbon revolution simultaneously in this 21 st century.

Society is like a large, heavy vessel that can change its course only slowly though. Now we understand which technical and agricultural changes are necessary and have the knowledge to realise them, economic, political, cultural and psychological hurdles must be overcome in order to keep the vessel of society turning away from the iceberg in front of us. Grand narratives paved the way for such big societal changes in the past. Stories about kings being appointed by the gods were the basis for the acceptance of their rule and the resulting efficient cooperation of thousands or even millions of people (Harari 2014: 106), stories 
about the American dream inspired a mass migration to the New World and stories about work and wealth in industrial towns lead and still leads to urbanization.

What we may need now is a new "grander narrative" (Zehner 2012 - epilogue), one that can be stronger than the narratives that are misguiding our current industrial societies. The story of Sustainable Development can be a story that remains inspiring and hopeful even in disasters that may come. A light at the horizon, something to fight for.

\section{References}

Biedermann P.H.W., Müller J., Grégoire J.C., Gruppe A., Hagge J., Hammerbacher A., Hofstetter R.W., Kandasamy D., Kolarik M., Kostovcik M., Krokene P., Sallé A., Six D.L., Turrini T., Vanderpool D., Wingfield M.J., Bässler C. (2019), Bark beetle population dynamics in the Anthropocene: challenges and solutions, "Trends in Ecology and Evolution", vol. 34 no. 10, pp. 914924, https://doi.org/10.1016/j.tree.2019.06.002.

Brundtland, G.H. (Ed.) (1987), Report of the World Commission on Environment and Development: our common future, Oxford University Press, London.

Darwin Ch. (1859), On the origin of species by means of natural selection or the preservation of favoured races in the struggle for life, John Muray publishers, London.

Glaubrecht, M. (2019), Das Ende des Evolution - Der Mensch und die Vernichtung der Arten (The end of evolution - Man and the annihilation of species), Bertelsmann Verlag, München.

Halliday T.J.D., Upchurch, P., Goswami A. (2016), Eutherians experienced elevated evolutionary rates in the immediate aftermath of the Cretaceous-Palaeogene mass extinction, Dryad, Dataset, https://doi.org/10.5061/dryad.0nr5s.

Harari Y. (2014), Sapiens, A brief history of humankind, HarperCollins, London.

Lieberman, D., Bramble, D. (2007), The evolution of marathon running, "Sports Med", vol 37 no. 4-5, pp. 288-290,.https://doi.org/10.2165/00007256-200737040-00004.

Lowery Ch., Fraass A (2019), Morphospace expansion paces taxonomic diversification after end Cretaceous mass extinction, "Nature Ecology \& Evolution", vol. 3 no. 6, pp. 900-904, https://doi.org/10.1038/s41559-019-0835-0.

New International Version. Bible Gateway, www.biblegateway.com [04.09.2020].

Zehner O. (2012), Green illusions: The dirty secrets of clean energy and the future of environmentalism, University of Nebraska Press, 2012. 